\title{
The Critically Endangered Mediterranean monk seal Monachus monachus in the archipelago of Madeira: priorities for conservation
}

\author{
Rosa Pires, Henrique Costa Neves and Alexandros A. Karamanlidis
}

\begin{abstract}
The Mediterranean monk seal is categorized as Critically Endangered on the IUCN Red List and is in urgent need of effective conservation measures. Following a steep decline in the 20th century, the National Park Service of Madeira initiated efforts to protect the species in the archipelago of Madeira, including habitat protection, scientific research and public awareness. The aim of this study was to analyse data collected during a monitoring project (1988-2005) to assess the conservation status of the species and identify priority conservation actions for the future. The study recorded the presence of the species at key pupping sites in a strictly protected area at the Desertas Islands, increased sightings in recent years around the main island of Madeira, an increase in the number of pups born, and low mortality. The population in the archipelago of Madeira is currently estimated to be 20-30 adults. These findings suggest that the species remains Critically Endangered in the area but that its conservation situation has improved because of the implementation of effective conservation actions. Conservation priorities identified include protecting suitable monk seal habitat at Madeira, investigating seal-fisheries interactions, increasing environmental education, and strengthening regional legislation for the protection of the species.
\end{abstract}

Keywords Conservation status, Madeira, management, marine protected area, Mediterranean, Monachus monachus, monk seal.

\section{Introduction}

The example of the Yangtze river dolphin, or baiji, Lipotes vexillifer, now almost certainly extinct (Turvey et al., 2007), is a warning of the possible fate of other freshwater and marine mammals. Despite nearly 30 years having passed, for example, since the first warnings of the

Rosa PIREs (Corresponding author) Parque Natural da Madeira, Quinta do Bom Sucesso, Caminho do Meio, 9064-512 Funchal, Portugal. E-mail rosapnm@hotmail.com

Henrique Costa Neves Department of the Environment, Science and Culture, Municipality of Funchal, Praça do Município, 9000-072 Funchal, Portugal.

Alexandros A. Karamanlidis MOm/Hellenic Society for the Study and Protection of the Monk Seal, 18 Solomou Street, 10682 Athens, Greece.

Received 29 September 2006. Revision requested 15 December 2006. Accepted 3 February 2007. species' demise (Sergeant et al., 1978), the Mediterranean monk seal Monachus monachus remains Critically Endangered (IUCN, 2007) and $<600$ individuals are estimated to survive in isolated populations in the north-eastern Mediterranean, the Cabo Blanco Peninsula in Western Sahara, and the archipelago of Madeira in the Atlantic. The main threats to the species' survival include habitat loss, intentional killing and accidental entanglement in fishing gear (Johnson et al., 2006). Effective conservation measures are urgently required to prevent the species' extirpation.

At the time of the arrival of the first Europeans to the island of Madeira in 1420 the Mediterranean monk seal was abundant. Portuguese settlers encountered, in what is now the City of Câmara de Lobos (the Chamber of Seals) at Madeira, seals hauling out in large numbers on an open beach and on small beaches inside caves (Barros, 1570, in Borges et al., 1978) and exploited them for their pelts and oil (Machado, 1979). Uncontrolled commercial exploitation and an increase in human activity led to a sharp decline in numbers throughout the island (Borges et al., 1978; Machado, 1979; Biscoito, 1988). In 1978 only six individuals were frequenting the main island of Madeira (Machado, 1979) and another 50 were thought to remain on the Desertas Islands (Sergeant et al., 1978). The intensification and expansion of fishing activities throughout the area, and increased deliberate and accidental killings by entanglement, led to the decline of the species on the Desertas Islands (Neves \& Pires, 1998; Neves \& Pires, 1999), and in the 1980 on only 6-8 individuals were estimated to survive there (Reiner \& dos Santos, 1984; Biscoito, 1988; Marchessaux, 1989).

To halt this decline the National Park Service of Madeira (Parque Natural da Madeira Service) initiated a Monk Seal Conservation and Monitoring Programme in 1988, and the Desertas Islands were declared a Nature Reserve in 1990. The conservation initiatives that have been carried out are, in order of importance: effectively enforcing legislation for the protection of the species and its habitat, creating conditions for the rehabilitation and recovery of sick and injured animals, monitoring and studying the Mediterranean monk seal throughout the archipelago, and informing and sensitizing the general public in Madeira, and fishermen in particular, concerning the species' threatened status (Neves \& Pires, 1999; Pires \& Neves, 2001). The aims of this study were to record the distribution, relative abundance, and basic demographic parameters of the Mediterranean monk seal in the archipelago of Madeira, and thus assess 
the species' conservation status and identify priority protection and management actions for the future.

\section{Study area}

The archipelago of Madeira is in the Atlantic Ocean, southwest of Portugal (Fig. 1). It comprises two inhabited islands, the main islands of Madeira and Porto Santo, and two uninhabited sub-archipelagos: the Desertas Islands (Ilhéu Chão, Deserta Grande and Bugio) south-east of Madeira, and the Selvagens Islands (Selvagem Grande, Selvagem Pequena and Ilhéu de Fora) south of Madeira (Fig. 1). The Reserve boundary of the Desertas Islands Nature Reserve is defined by the $100 \mathrm{~m}$ depth isobath. The entire northern half of the protected area has the status of a partial reserve, where human activity is controlled (i.e. navigation, snorkelling and professional and amateur fishing without nets is allowed). The southern half, including the most important pupping sites for the species in the area (Silva, 1999; Karamanlidis et al., 2004), has the status of a strict reserve. Human activity, except traditional tuna fishing, which is an important economic resource in the region and is not considered to be a threat to the species, is prohibited. The Reserve is guarded by wardens who patrol the area whenever weather conditions permit.

\section{Methods}

\section{Desertas Islands Nature Reserve}

Systematic monitoring of Mediterranean monk seals at the Desertas Islands Nature Reserve has been carried out from 1992 and is based on two methods: observations of monk seals from lookout sites, and observations made whilst navigating by boat around the islands of the Reserve.
Applying a strictly non-invasive approach to studying the species and based on information of preferred monk seal habitat (Silva, 1999; Karamanlidis et al., 2004) six lookout-sites were established (Fig. 2). During observation with binoculars, standard forms, containing date, observation point, observer, and start and end times, were noted. To evaluate relative population abundance in the area annual sighting frequency and individuals sighted per effort were calculated. Annual sighting frequency for a lookoutsite was calculated as the number of successful hours of observation in a year divided by the total hours of observation effort, and individuals sighted per effort as the sum of the individuals observed divided by the total number of hours of observation effort per year.

Observations of Mediterranean monk seals during circumnavigation of the Reserve in an inflatable boat were carried out within the framework of the guarding efforts of the Park authorities and did not follow a strict observation protocol as they were subject to short-term changes based on management priorities. Annual sighting frequencies and individuals sighted per effort could therefore not be determined for this method. Monitoring effort during circumnavigation was primarily for recording mortality and natality events and species distribution within the Reserve.

When seals were observed their characteristics were recorded and photographs and/or video taken. A catalogue of individuals identified in the area was created, facilitated by the presence of distinctive marks and scars (Marchessaux \& Muller, 1987). Classification of individuals was based on the morphological groups defined by Gonzàlez et al. (1996) and Samaranch \& Gonzàlez (2000): pup, youngster, juvenile, medium-sized seal, large-sized seal, and large black male seal. Occasionally the behaviour of seals during mating and nursing aided in the determination of the gender of adult individuals. The gender of the pups was

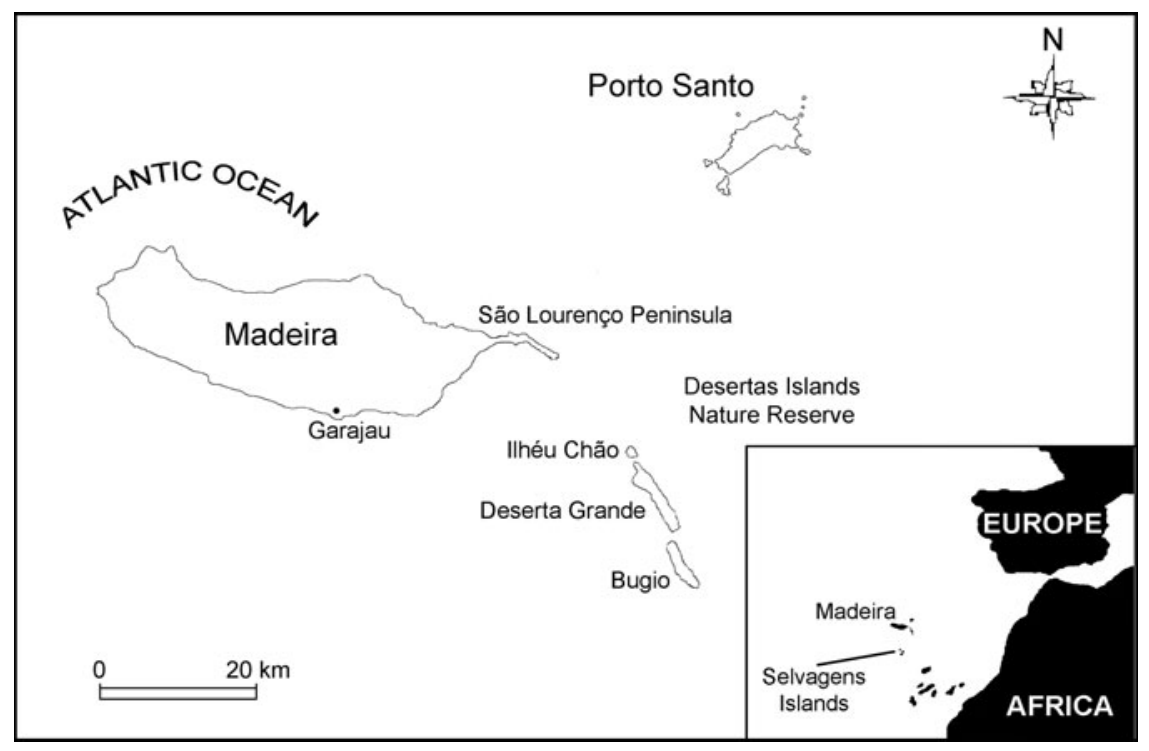

FIG. 1 The archipelago of Madeira, indicating the locations mentioned in the text. The inset indicates the location of Madeira off the west coast of Africa. 


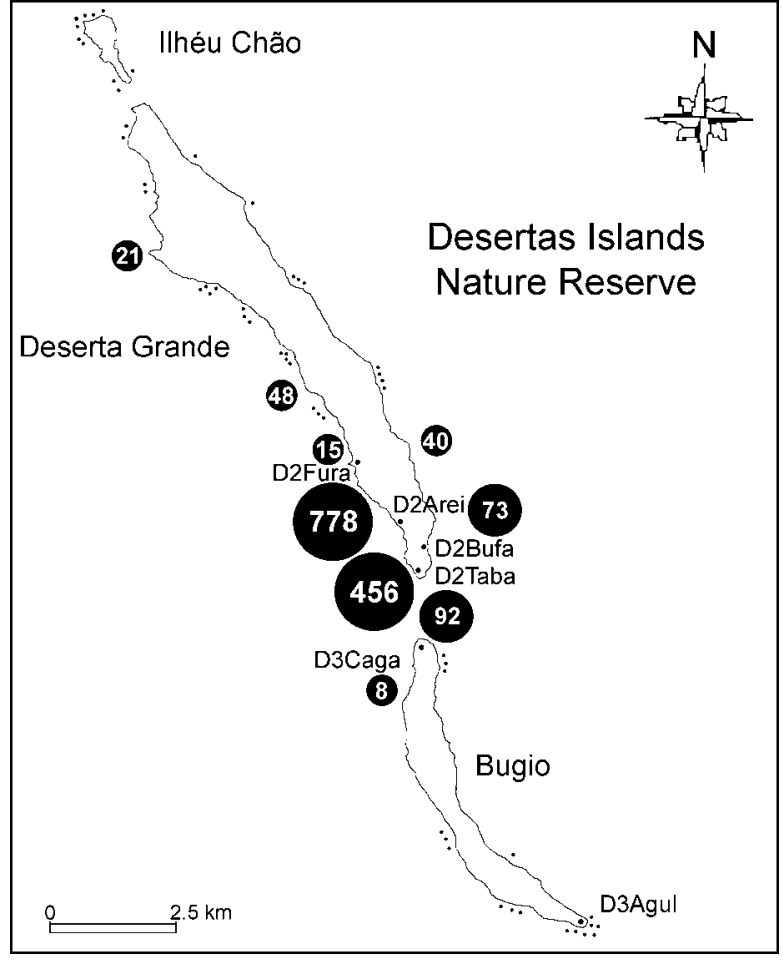

FIG. 2 Desertas Islands Nature Reserve, showing the locations of the six lookout sites (with prefix D2 or D3) and the locations and numbers of monk seal sightings (in circles) during 1992-2005.

determined by direct observation of the genitalia or, if too distant, by the shape of the sexually dimorphic ventral patches (Badosa et al., 1998). Time of birth was based on the morphological stage of the pup when observed for the first time, as proposed by Dendrinos et al. (2000).

\section{Madeira, Porto Santo and the Selvagens Islands}

From 1988 to 2001 assessment of the status of the monk seal population at the main island of Madeira was based on circumstantial reports of sightings received by Parque Natural da Madeira Service. Reacting, however, to an increasing number of such reports, an effort to collect these systematically was initiated by the Service in 2002, and a Monk Seal Information Network established. Following a public information and awareness campaign that focused on target groups from the coastal areas of the island, such as fishermen, operators and employees of beach resorts, marinas, and scuba diving centres, local people were requested to report monk seal sightings. Monk seal encounter forms were distributed, requesting information on the date, time, place and behaviour of the seal during the encounter.

There is no historical evidence indicating the presence of the Mediterranean monk seal either at Porto Santo or the sub-archipelago of the Selvagens Islands. Evaluation of the status of the species at Porto Santo was based on circumstantial evidence received by Parque Natural da Madeira
Service. Although no systematic efforts were carried out to monitor the species at the small islands of the Selvagens sub-archipelago, members of the permanent warden station at Selvagem Grande, who patrol the area daily, were instructed to report encounters to the Monk Seal Information Network.

\section{Results}

\section{Distribution}

From 1992 to 2005 Mediterranean monk seals were monitored for a total of 13,099 hours at the Desertas Islands Nature Reserve (5,501 hours from lookout sites; 7,598 hours circumnavigating the Reserve), during which 1,585 Mediterranean monk seal sightings were recorded (Fig. 2; lookout sites, 1,258 sightings, 2,129 animals in total sighted; circumnavigation of the Reserve, 327 sightings, 528 animals in total sighted; Table 1).

From 1988 to 2005 Parque Natural da Madeira Service received or collected 387 reports of Mediterranean monk seal sightings from the main island of Madeira (1988-2001, $\mathrm{n}=49$; 2002-2005, $\mathrm{n}=338$; Table 2, Fig. 3). Based on information from these reports and field visits carried out by Service staff, the use by the species of one cave in the south-eastern part of the island was confirmed in 2002. Monk seal sightings from Madeira since 2000 include a number of human-seal interactions (damage to fishing lines, $\mathrm{n}=4$; interactions with speargun fishermen, $\mathrm{n}=8$; interactions with scuba divers, $\mathrm{n}=2$; damage to fishing

TABLE 1 Observation effort (hours) for the Mediterranean monk seal during circumnavigation of Desertas Islands Nature Reserve and from lookout sites (Fig. 2), with total number of sightings and of individuals observed during 1992-2005.

\begin{tabular}{|c|c|c|c|c|c|c|}
\hline \multirow[b]{2}{*}{ Year } & \multicolumn{3}{|c|}{ Circumnavigating Reserve } & \multicolumn{3}{|c|}{ Lookout sites } \\
\hline & $\begin{array}{l}\text { No. of } \\
\text { hours }\end{array}$ & $\begin{array}{l}\text { No. of } \\
\text { sightings }\end{array}$ & $\begin{array}{l}\text { No. of } \\
\text { seals seen }\end{array}$ & $\begin{array}{l}\text { No. of } \\
\text { hours }\end{array}$ & $\begin{array}{l}\text { No. of } \\
\text { sightings }\end{array}$ & $\begin{array}{l}\text { No. of } \\
\text { seals seen }\end{array}$ \\
\hline 1992 & 399 & 9 & 13 & 415 & 68 & 100 \\
\hline 1993 & 500 & 19 & 27 & 334 & 107 & 222 \\
\hline 1994 & 515 & 8 & 8 & 319 & 113 & 165 \\
\hline 1995 & 510 & 13 & 16 & 389 & 94 & 143 \\
\hline 1996 & 407 & 15 & 19 & 194 & 25 & 43 \\
\hline 1997 & 540 & 15 & 24 & 631 & 129 & 211 \\
\hline 1998 & 439 & 18 & 21 & 475 & 91 & 153 \\
\hline 1999 & 493 & 32 & 48 & 451 & 88 & 154 \\
\hline 2000 & 612 & 39 & 81 & 375 & 50 & 97 \\
\hline 2001 & 612 & 38 & 80 & 272 & 36 & 92 \\
\hline 2002 & 578 & 34 & 67 & 243 & 37 & 50 \\
\hline 2003 & 679 & 33 & 41 & 495 & 151 & 240 \\
\hline 2004 & 802 & 34 & 53 & 515 & 150 & 264 \\
\hline 2005 & 512 & 20 & 30 & 393 & 119 & 195 \\
\hline Total & 7,598 & 327 & 528 & 5,501 & 1,258 & 2,129 \\
\hline
\end{tabular}


TABLE 2 Sightings of the Mediterranean monk seal around Madeira and Porto Santo (Fig. 1) during 1988-2005.

\begin{tabular}{lclr}
\hline Year & Madeira & Porto Santo & Total \\
\hline $1988-1996$ & 0 & 0 & 0 \\
1997 & 1 & 0 & 1 \\
1998 & 7 & 1 & 8 \\
1999 & 12 & 0 & 12 \\
2000 & 20 & 0 & 20 \\
2001 & 9 & 0 & 9 \\
2002 & 66 & 0 & 66 \\
2003 & 103 & 0 & 103 \\
2004 & 122 & 1 & 123 \\
2005 & 47 & 0 & 47 \\
Total & 387 & 2 & 389 \\
\hline
\end{tabular}

traps, $\mathrm{n}=10$; damage to aquaculture installations, $\mathrm{n}=$ 12). Although such interactions with humans may be potentially threatening to the species, the Service has not received reports of harmful behaviour towards monk seals. Two monk seal sightings were reported from Porto Santo, but none from the Selvagens Islands.

\section{Relative abundance}

The observation effort carried out at the six lookout sites at Desertas Islands Nature Reserve totalled 5,501 hours, during which 1,258 Mediterranean monk seal sightings were recorded. Average group size of seals at sea was $1.72 \pm \mathrm{SE}$ 0.03 and maximum group size was six. In December 2005 a group of nine individuals was observed, six of which were using an open beach in the strictly protected part of the Reserve (Plate 1). Annual sighting frequencies and individuals sighted per effort did not differ significantly during the monitoring period (annual sighting frequency, one way ANOVA $F=0.489, \mathrm{P}=0.924$; individuals sighted per effort, one way ANOVA $F=0.355, \mathrm{P}=0.979$; Fig. 4).

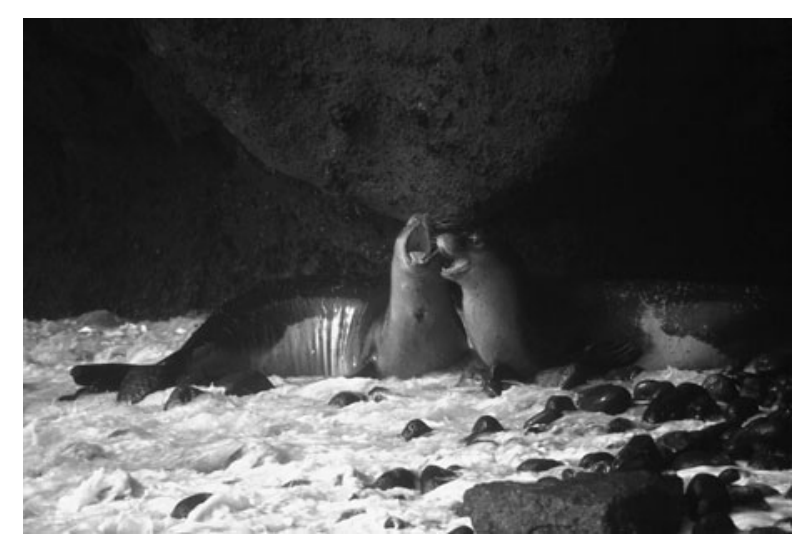

Plate 1 Two adult female Mediterranean monk seals interacting on an open beach in the strictly protected part of the Desertas Islands Nature Reserve (Fig. 2) (photo by Rosa Pires).

\section{Identification of individuals}

In many instances neither sex nor individual identity could be determined. Similarly, difficulties were encountered when assigning age classes to all but new-born individuals. By the time the study was completed in 2005, five black males, six large-sized females, two large-sized males, two mediumsized seals and three juveniles had been individually identified. From the information collected during monitoring at the Desertas Islands Nature Reserve and based on visual documentation provided by reports from Madeira we confirmed the presence of three individuals identified for the first time in the Reserve around the island of Madeira, and two (one black male and one large-sized male), that have been sighted so far only at the island of Madeira.

\section{Mortality}

Over 1989-2005 four deaths were recorded at the Desertas Islands Nature Reserve, all involving pre-weaned pups that

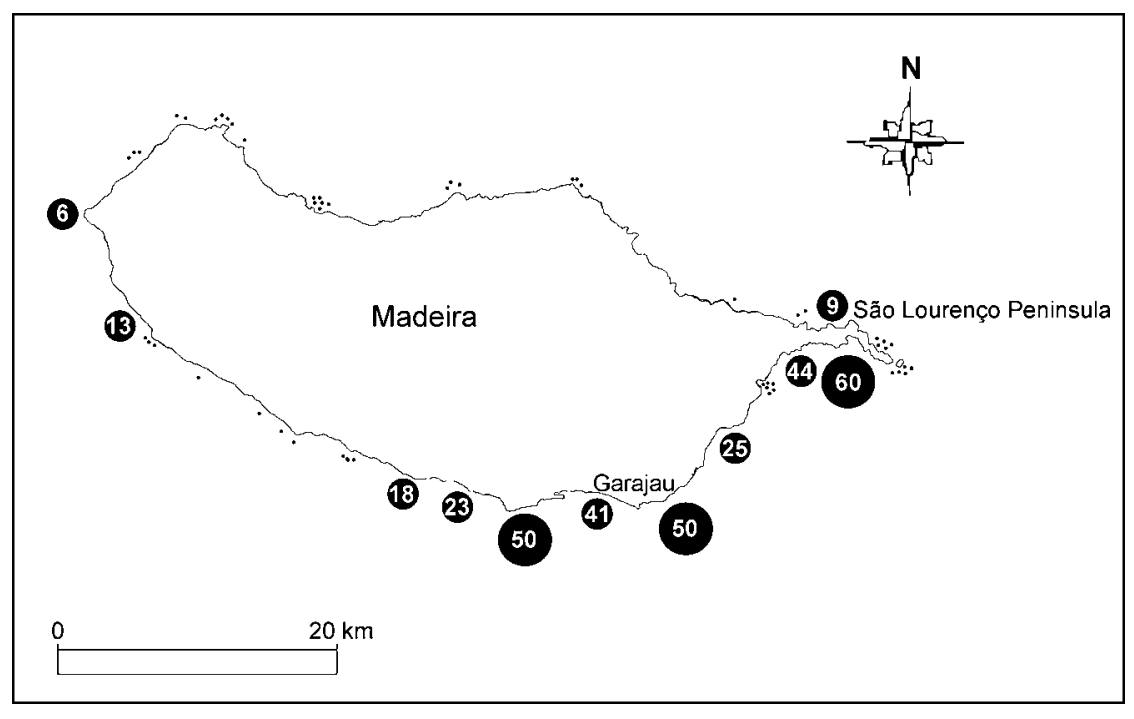

FIG. 3 The island of Madeira showing the location and number of monk seal sightings (in circles) received or collected by Parque Natural da Madeira Service during 1988-2005. 


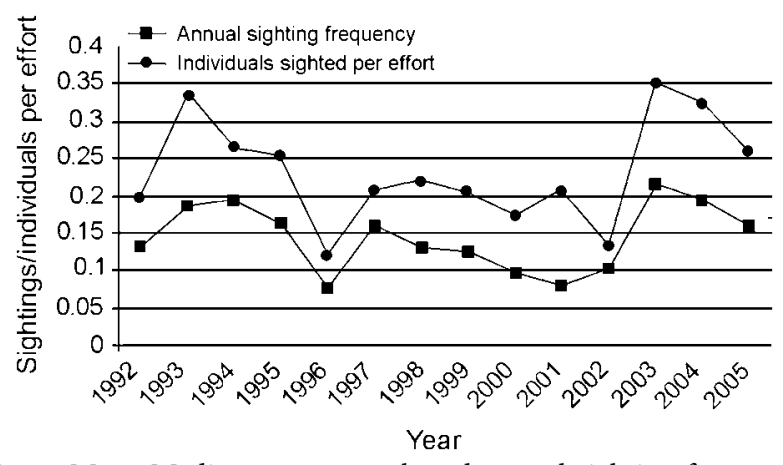

FIG. 4 Mean Mediterranean monk seal annual sighting frequency and individuals sighted per effort (see text for details) recorded at the six lookout sites in the Desertas Islands Nature Reserve (Fig. 2) during 1992-2005.

were found dead either after heavy storms $(\mathrm{n}=3)$ or, in one case, lost contact with its mother during a heavy storm and died from septicaemia during rehabilitation. In Madeira a juvenile monk seal was found dead after a heavy storm in November 2004. The advanced decomposition stage of all four carcasses found did not permit the determination of the cause of death. The number of deaths recorded represents a minimum number as not all possible deaths would necessarily have been recorded (e.g. some carcasses may have drifted out to sea).

\section{Natality}

From 1989 to 200535 pups were recorded (nine females, eight males, 18 undetermined). Annual birth rate increased significantly $\left(r^{2}=0.759, F=47.120, \mathrm{P}<0.005\right)$ from one pup in 1989 to three pups in 2001 (Fig. 5), while the number of births differed significantly within the year (Kruskal Wallis $x^{2}=86.992$, $\left.\mathrm{df}=11, \mathrm{P}<0.005\right)$, with a peak in November (Fig. 6). Thirty-four newborn pups were detected for the first time in the strictly protected part of the Reserve in south Deserta Grande. One stranded pup was observed for the first time at the warden station at Doca,

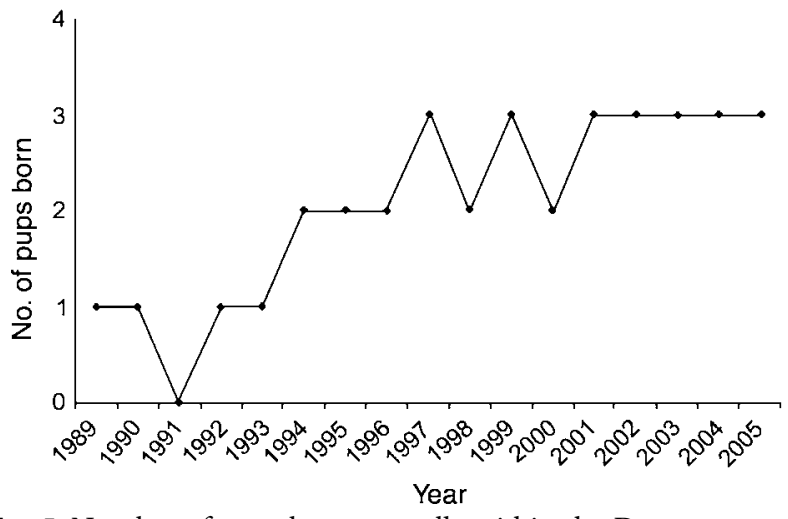

FIG. 5 Number of pups born annually within the Desertas Islands Nature Reserve (Fig. 2) during 1989-2005. and was subsequently returned to its mother at the beach next to the cave at the lookout site D2Taba (Fig. 2). During the study five reproductive females were identified. In 1997 mothers were observed for the first time taking care of their offspring on an open beach in south-west Deserta Grande. Since then mother-pup pairs have been using the same open beach annually.

\section{Discussion}

According to Red List criterion C2a (species population estimated to be $<250$ mature individuals, and a continuing decline observed, projected, or inferred in numbers of mature individuals, and population structure that is highly fragmented, with no subpopulation estimated to contain $>_{50}$ mature individuals; IUCN, 2001), the Mediterranean monk seal is categorized globally as Critically Endangered. The species is also categorized as Critically Endangered in the Portuguese Red Data Book (Queiroz et al., 2005) and is fully protected under national and regional laws (Decree law no. 263/81 and Regional Legislative Decree no. 6/86/M).

The 18 individuals identified during this study do not represent an accurate estimate of the actual size of the Mediterranean monk seal population in the area. By the time the study was completed several individuals were still young and did not bear sufficiently distinctive marks for them to be positively identified. In addition, the inaccessibility of the species' habitat and the firm commitment to the application of non-invasive research methodologies have prevented the use of methods such as marking or satellite tracking that would provide data for more accurate population estimates. Based on the available data, demographic data from the colonies at Cabo Blanco (Forcada et al., 1999; Gazo et al., 1999) and the Northern Sporades in Greece (MOm, 2007; ratio of newborn pups to total population size) and comparing with data from a subpopulation in Northern Karpathos/Saria in Greece that has similar demographic parameters (five reproductive caves; annual birth rate 1998-2004 $=3.7$; two recorded deaths during 2000-2004; MOm, 2005, 2007), we estimate the subpopulation in the archipelago of Madeira to be 20-30 adult individuals. We conclude therefore that the Mediterranean monk seal is Critically Endangered locally in the archipelago of Madeira, as the size of the population is most likely $<50$ adult individuals.

Although a direct comparison with the population estimates (Reiner \& dos Santos, 1984; Biscoito, 1988; Marchessaux, 1989) for the time immediately prior to the initiation of the Monk Seal Conservation and Monitoring Programme is not possible, because of differences in methodologies and the short-term nature of these earlier efforts, the results of our study suggest that the conservation situation for the species in the archipelago of Madeira has not worsened since the initiation of conservation actions. Two facts in particular 


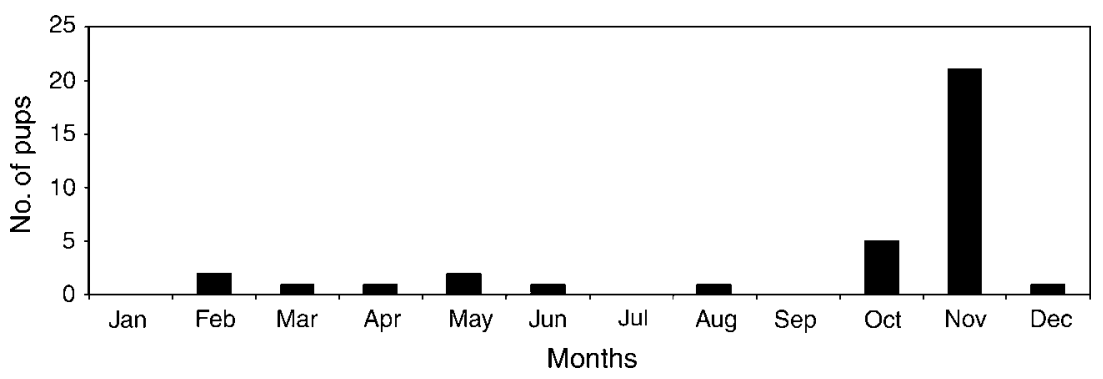

FIG. 6 Mean number of pups born monthly within the Desertas Islands Nature Reserve (Fig. 2) during 1989-2005. indicate that the conservation situation of the species in the area has improved:

Firstly, the monk seal is now using an increased area of habitat. Restricted by the 1980 s to the islands of the Desertas sub-archipelago (Reiner \& dos Santos, 1984; Biscoito, 1988; Marchessaux, 1989), the species' stronghold still remains at these islands. Observations of monk seals during the monitoring period occurred around all three islands of the sub-archipelago, with an increased number of sightings taking place in the strictly protected part of the Reserve, close to the key pupping sites at southern Deserta Grande. During 2002-2005, however, the number of monk seal sightings reported from Madeira, especially the southern side closest to the Desertas Islands Nature Reserve, has increased. Dispersing individuals have been sighted as far as the island of Porto Santo. It is difficult to evaluate the extent to which this increase can be attributed to the actual increase of animals at Madeira or to the environmental awareness campaign and higher reporting rates of monk seal encounters. Our results have confirmed, however, the interchange of individuals between the Desertas Islands Nature Reserve and the island of Madeira and the use of coastal habitat at Madeira. Furthermore, we have confirmed the occupation of open beaches at the Reserve. Historical evidence indicates that hauling out on open beaches was frequently observed in the past and that therefore the current almost exclusive use of sea caves as terrestrial habitat is a result of ongoing human disturbance (Johnson \& Lavigne, 1999). The elimination of human disturbance from the terrestrial habitat of the species within the Desertas Islands Nature Reserve, which has been achieved through the strict enforcement of protection measures and the endorsement of the Parque Natural da Madeira Service management plan for the Reserve, in combination with the awareness campaigns carried out at Madeira, account for the diminishing threat of habitat deterioration.

Secondly, there has been an increase of births within the Desertas Islands Nature Reserve and only low mortality was recorded. Most importantly, none of the deaths recorded was attributed to deliberate or accidental killings, threats that affected the species severely in the past and that are still significant mortality factors elsewhere in the species' range (Johnson et al., 2006). Accidental killing through entan- glement in fishing gear affects subadults in particular (Karamanlidis et al., in press) and has been considered responsible for the loss of several monk seals on the Aegean coast of Turkey (Veryeri et al., 2001). Deliberate killing, in contrast, affects mostly adults (Androukaki et al., 2006) and is considered to be a result of seal-fisheries conflict (Johnson \& Karamanlidis, 2000). The exclusion, therefore, of human activity from key areas in the south of Desertas Islands Nature Reserve, in combination with controlled fishing activities in the northern part of the Reserve and the environmental education carried out amongst fishermen at Madeira, are considered to have contributed to the reduction in the effect of these mortality factors.

Based on our findings we identify four main conservation priorities for the survival of the Critically Endangered Mediterranean monk seal in the archipelago of Madeira:

(1) Habitat protection remains the outstanding priority. The successful protection and management scheme in the Desertas Islands Nature Reserve is currently also implemented at the protected areas of the São Lourenço Peninsula and Garajau at Madeira, where potentially suitable monk seal habitat (suitable resting and pupping caves) has been identified (Karamanlidis et al., 2003). However, to define an effective conservation strategy for the species across Madeira, further information on habitat availability, suitability and use is required. Habitat surveys should be carried out across the entire island and frequently used areas should be monitored using the non-invasive scheme applied at the Desertas Islands Nature Reserve.

(2) Since the initiation of the Monk Seal Conservation and Monitoring Programme knowledge of demography (Pires, 1997; Pires \& Neves, 2001), habitat requirements and use (Silva, 1999; Karamanlidis et al., 2004) and activity patterns (Pires, 1997; Pires et al., 2007) of the species in the area has increased significantly. Taking into account the presence of monk seals at the island of Madeira and the potential conflicts arising with humans, research should focus on understanding the nature of these interactions.

(3) The documented presence of the Mediterranean monk seal around the island of Madeira has increased the importance of public information and sensitization efforts. Intensifying such efforts towards target groups that are most likely to interact with the species, such as fishermen, 
beachgoers and tourists, will play a key role in any reestablishment of a resident monk seal colony at Madeira.

(4) Current regional legislation for the protection of the Mediterranean monk seal prohibits the deliberate killing of seals but does not consider deliberate harassment or injury. Recognizing the ecological importance of the species for Madeira, where natural resources are amongst the main tourist attractions, the government of Madeira is modifying the existing legislation so that it takes such threats into account. Given that the protection of the monk seal, as part of the marine ecosystem, falls within the jurisdiction of the local port police authorities, their active involvement in the protection of the species, through the patrolling of coastal Madeira, must also be reinforced.

In accordance with the conservation priorities identified in this study and the guidelines of the Action Plan for the Recovery of the Mediterranean Monk Seal in the Eastern Atlantic (González et al., 2006), the Parque Natural da Madeira Service carried out a survey in 2007 in the eastern part of Madeira (Pires \& Gazo, 2007) to identify suitable monk seal habitat that could be protected within the framework of the Special Areas of Conservation for the monk seal in the Atlantic. The establishment of a well-managed and wellguarded network of marine protected areas is of paramount importance for the species' recovery (Israëls, 1992; Johnson \& Lavigne, 1998; González et al., 2006). However, until now, countries with monk seal populations have been slow in establishing such areas and in securing funding for their effective operation. In 2005 there were no fully-functioning marine protected areas for the monk seal in the Mediterranean basin (Johnson et al., 2006). Such delays in the designation and operation of marine protected areas for the species led to the consideration of ex situ efforts to safeguard the species, although such initiatives have been treated with scepticism (Johnson \& Lavigne, 1994, 1998). Considering the case of the almost certainly extinct baiji, a species for which detailed conservation priorities had been identified (Braulik et al., 2006), it is clear that too little was done too late for the survival of this species. The case of monk seal conservation in the archipelago of Madeira shows however that positive results can be achieved even in a short time frame, and that ex situ conservation actions for the species should be considered only after all possibilities for in situ conservation have been actively pursued.

\section{Acknowledgements}

We thank the staff of the Parque Natural da Madeira Service and particularly the Reserve wardens who have been key to the Monk Seal Conservation and Research Programme, the Regional Government of Madeira through the Regional Secretary of Environment and Natural Resources for financial support and personal interest, and the
Portuguese Navy for help in patrolling the Nature Reserve and for the transport of staff and equipment. Jim Valade and two anonymous reviewers provided insightful comments that improved the manuscript. Special thanks go to the volunteers and students who spent countless hours on rocks waiting for monk seals. The European Commission LIFE projects 6616/1/87, B/6610/89/76, 6610(90)9163, 4$3010(92) 7791, \quad B 4-3200 / 94 / 765$ and B4-3200/98/501 funded this study.

\section{References}

Androukaki, E., Chatzispyrou, A., Adamantopoulou, S., Dendrinos, P., Komnenou, A., Kuiken, I. et al. (2006) Investigating the causes of death in monk seals stranded in coastal Greece (1986-2005). In 2oth Conference of the European Cetacean Society (ed. I. Kuklik), pp. 112. ECS, Gdynia, Poland.

Badosa, E., Grau, E., Aparicio, F., Layna, J.F. \& Cenenilla, M.A. (1998) Individual variation and sexual dimorphism of coloration in Mediterranean monk seal pups (Monachus monachus). Marine Mammal Science, 14, 390-393.

Biscoito, M.J. (1988) Lobos Marinhos: que futuro? Islenha, 3, $100-104$.

Borges, J.G., Maul, G.E., De Vasconcellos, G.M. \& Zino, P.A. (1979) The monk seals of Madeira. In First International Conference on the Mediterranean Monk Seal, Rhodes, Greece (eds K. Ronald \& R. Duguy), pp. 63-64. Pergamon Press, Oxford, UK.

Braulik, G., Reeves, R.R., Ding, W., Ellis, S., Wells, R.S. \& Dudgeon, D. (2006) Report of the Workshop on Conservation of the Baiji and Yangtze Finless Porpoise. Wuhan, China, 28 Nov. - 3 Dec. 2004. Federal Office for the Environment, Zurich, Switzerland.

González, L.M., Mas, J., Herrera, R., Larrinoa, P.F., Moumni, A., Idrissi, H. et al. (2006) Action Plan for the Recovery of the Mediterranean Monk Seal in the Eastern Mediterranean. Naturaleza y Parques Naclonales, Series Especies Amenazadas. Serricio de Publicaciones del Ministerio de Medio ambiente, Madrid, Spain.

Dendrinos, P., Tounta, E. \& Kotomatas, S. (200o) A field method for age estimation of Mediterranean monk seal pups. The Monachus Guardian, 3, 72-74.

Forcada, J., Hammond, P.S. \& Aguilar, A. (1999) Status of the Mediterranean monk seal Monachus monachus in the western Sahara and the implications of a mass mortality event. Marine Ecology Progress Series, 188, 249-261.

Gazo, M., Layna, J.F., Aparicio, F., Cedenilla, M.A., Gonzalez, L.M. \& Aguilar, A. (1999) Pupping season, perinatal sex ratio and natality rates of the Mediterranean monk seal from the Cabo Blanco colony. Journal of Zoology, 249, 393-401.

Gonzàlez, L.M, Grau, E., López-Jurado, L.F., Aguilar, A. \& SAMARANCH, R. (1996) Variation with age and sex of pelage coloration in monk seals (Monachus monachus) from Cabo Blanco. European Research on Cetaceans, 10, 313-315.

IsRAËLS, L.D.E. (1992) Thirty years of Mediterranean monk seal protection - a review. Mededelingen, 28, 1-65.

IUCN (2001) 2001 Categories and Criteria (version 3.1). IUCN, Gland, Switzerland [http://www.iucnredlist.org/info/categories_criteria 2001.html, accessed 14 September 2007].

IUCN (2007) 2007 IUCN Red List of Threatened Species. IUCN, Gland, Switzerland. Http://www.iucnredlist.org [accessed 30 January 2008]. 
Johnson, W.M. \& Karamanlidis, A.A. (2000) When fishermen save seals. The Monachus Guardian, 3, 18-22.

Johnson, W.M., Karamanlidis, A.A., Dendrinos, P., DE LarrinoA, P.F., Gazo, M., GonzÀlez, L.M. et al. (2006) Monk Seal Fact Files. Mediterranean Monk Seal (Monachus monachus). Http://www.monachus-guardian.org./factfiles/medito1.htm [accessed 10 March 2008].

Johnson, W.M. \& Lavigne, D.M. (1994) Captive Breeding and the Mediterranean Monk Seal - A Focus on Antibes Marineland. International Marine Association, Guelph, Canada.

Johnson, W.M. \& Lavigne, D.M. (1998) The Mediterranean Monk Seal. Conservation Guidelines. International Marine Association, Guelph, Canada.

Johnson, W.M. \& Lavigne, D.M. (1999) Monk seals in antiquity. The Mediterranean monk seal (Monachus monachus) in ancient history and literature. Mededelingen, 35, 1-101.

Karamanlidis, A.A., Androukaki, E., Adamantopoulou, S., Chatzispyrou, A., Johnson, W.M., Kotomatas, S. et al. (in press) Assessing accidental entanglement as a threat to the Mediterranean monk seal. Endangered Species Research.

Karamanlidis, A.A., Pires, R., Neves, H.C. \& Santos, C. (2003) Habitat of the endangered Mediterranean monk seal (Monachus monachus) at Sâo Lourenço-Madeira. Aquatic Mammals, 29, $400-403$.

Karamanlidis, A.A., Pires, R., Silva, N.C. \& Neves, H.C. (2004) The availability of resting and pupping habitat for the Critically Endangered Mediterranean monk seal Monachus monachus in the archipelago of Madeira. Oryx, 38, 180-185.

Machado, A.J.M. (1979) Os Lobos Marinhos (Genero Monachus, Fleming 1822) - Contribuição para o seu estudo e protecção. Unpublished Report. Museu do Mar, Unidade de Mamalogia, Cascais, Portugal.

Marchessaux, D. (1989) Distribution et statut des populations du phoque moine Monachus monachus (Hermann, 1779). Mammalia, $53,621-642$.

Marchessaux, D. \& Muller, N. (1987) Le Phoque Moine, Monachus monachus: distribution, statut et biologie sur la cote saharienne. Scientific Reports of the Port Cros National Park, 13, 25-84.

MOм (2005) Status Report of the Mediterranean Monk Seal Populations in Kimolos-Polyaigos and Karpathos-Saria Areas. Final report to EC LIFE-Nature 2000 Project (LIFEooNAT/GR/7248). MOm/Hellenic Society for the Study and Protection of the Monk Seal, Athens, Greece.

MOM (2007) Status Report of the Mediterranean Monk Seal Monachus monachus Population in Greece. Unpublished Report to the Hellenic Ministry of Rural Development and Food, Athens, Greece.

Neves, H.C. \& Pires, R. (1998) Past and present trends of the Mediterranean monk seal (Monachus monachus Hermann 1779) on the Desertas Islands-Madeira. In The World Marine Mammal Science Conference. Workshop on the Biology and Conservation of the World's Endangered Monk Seals, Monaco, p. 49. The Society for Marine Mammalogy \& The European Cetacean Society, Monaco.
Neves, H.C. \& Pires, R. (1999) O Lobo Marinho no Arquipelago da Madeira. Parque Natural da Madeira, Funchal, Portugal.

Pires, R. (1997) Estado actual e aspectos da biologia e ecologia da colónia de lobos-marinhos, Monachus monachus, das Ilhas Desertas. Relatório de estágio para ingresso na carreira técnica. Serviço do Parque Natural da Madeira, Funchal, Portugal.

Pires, R. \& Gazo, M. (2007) Habitat survey around Madeira island. The Monachus Guardian, 10 July 2007. Http://www.monachusguardian.org/mguard19/1915mednew.htm\#Madeira [accessed 25 January 2008].

Pires, R. \& Neves, H.C. (2001) Mediterranean monk seal Monachus monachus conservation: a case study in the Desertas Islands. Mammalia, 65, 301-308.

Pires, R., Neves, H.C. \& Karamanlidis, A.A. (2007) Activity patterns of the Mediterranean monk seal (Monachus monachus) in the archipelago of Madeira. Aquatic Mammals, 33, 327-336.

Queiroz, A.I. (ed.) (2005) Monachus monachus Lobo-marinho. In Livro Vermelho dos Vertebrados de Portugal (eds M.J. Cabral, J. Almeida, P.R. Almeida, T. Dellinger, N. Ferrand de Almeida, M.E. Oliveira et al.), pp. 529-530. Instituto da Conservação da Natureza, Lisboa, Portugal.

Reiner, F. \& dos Santos, M. (1984) L'extinction imminente du phoque moine de Madere. In Second International Conference on the Monk Seals (eds K. Ronald \& R. Duguy), pp. 79-87. Annales de la Societe des Sciences Naturelles de la Charente-Maritime, La Rochelle, France.

SAmARANCh, R. \& GonZÀlez, L.M. (2000) Changes in morphology with age in Mediterranean monk seals (Monachus monachus). Marine Mammal Science, 16, 141-157.

Sergeant, D., Boulva, J., Berkes, F. \& Ronald, K. (1978) Recent status of Monachus monachus, Mediterranean monk seal. Biological Conservation, 14, 259-287.

Silva, N.C. (1999) Caracterização do habitat e distribuição temporal do lobo marinho, Monachus monachus, nas Ilhas Desertas. Licenciatura. University of Lisbon, Lisboa, Portugal.

Turvey, S.T., Pitman, R.L., Taylor, B.L., Barlow, J., Akamatsu, T., Barrett, L.A. et al. (2007) First human-caused extinction of a cetacean species? Biology Letters, 3, 537-540.

Veryeri, O., Güçlüsoy, H. \& Savaş, Y. (2001) Snared and drowned. The Monachus Guardian, 4, 29-33.

\section{Biographical sketches}

Rosa PIREs' research focuses on the conservation of threatened species and the management of protected areas in Madeira. She is currently carrying out a study on the reproductive parameters, social organization and activity patterns of the Mediterranean monk seal. Henrique Costa Neves has been the Director of the Parque Natural da Madeira for many years, and was the initiator of the Monk Seal Conservation and Monitoring Programme. He is currently involved in the environmental policy of the Municipality of Funchal, Madeira. Alexandros A. Karamanlidis is currently studying the marking behaviour and conservation genetics of brown bears in Greece, and is involved in the conservation and management of threatened mammals of the eastern Mediterranean region. 